\title{
Assessment of different in vitro sperm challenges and in vivo fertility of bovine semen batches
}

\author{
Avaliação de diferentes desafios espermáticos in vitro e \\ da fertilidade in vivo de partidas de sêmen bovino
}

\author{
Letícia Zoccolaro OLIVEIRA ${ }^{1}$; Lucas Bernardes RIBEIRO²; Luiz Gustavo Teodoro da SILVA; \\ Clara Slade OLIVEIRA; ${ }^{3}$ Erika Aline Ribeiro DIAS ${ }^{4}$; Suzane Peres CAMPANHOLI \\ Carla Cristian CAMPOS ; Maiana Visoná de OLIVEIRA ${ }^{5}$; Fabio Morato MONTEIRO ${ }^{4}$ \\ ${ }^{1}$ Universidade Federal de Minas Gerais, Escola de Veterinária, \\ Departamento de Clínica e Cirurgia Veterinárias, Belo Horizonte - MG, Brazil \\ ${ }^{2}$ Centro Universitário de Rio Preto, Faculdade de Medicina Veterinária, São José do Rio Preto - SP, Brazil \\ ${ }^{3}$ Centro Nacional de Pesquisa em Gado de Leite, Valença - RJ, Brazil \\ ${ }^{4}$ Instituto de Zootecnia, Sertãozinho - SP, Brazil \\ ${ }^{5}$ Universidade Federal de Uberlândia, Faculdade de Medicina Veterinária, Uberlândia - MG, Brazil
}

\begin{abstract}
The aim of this work was to submit sperm cells to different laboratory challenges and to compare in vitro results with in vivo semen fertility. Four different batches from the same Brangus bull were used in a timed-AI program of 332 Brangus cows. Each batch (B) was submitted to the following procedure: semen sample was thawed at $36^{\circ} \mathrm{C}$ for 30 seconds (control). Sperm motility parameters, plasma membrane integrity, sperm morphology, and concentration were assessed. Then, an aliquot of thawed sample was incubated in a water bath at $45^{\circ} \mathrm{C}$ for $40 \mathrm{~min}$ (thermal challenge group; TCG) and another aliquot was centrifuged at $500 \mathrm{xg}$ (Percoll gradient 45\%/90\%) for 15 min (centrifugation challenge group; CCG). Centrifuged semen was also submitted to another thermal challenge, being incubated (water bath) at $45^{\circ} \mathrm{C}$ for $40 \mathrm{~min}$ (centrifugation + thermal challenge group; CTCG). At the end of each challenge (CCG, TCG, and CTCG), the same laboratory tests used for control group were repeated. The following conception rates (CR) were observed for each batch: B1 = 48.9\% (44/90); B2 = 44.2\% (23/52); B3 = 55.5\% (40/72); B4 = 43.2\% (51/118); $(\mathrm{p}<0.10)$. In the lab, B3 presented higher $(\mathrm{p} \leq 0.05)$ progressive motility $(\mathrm{PM})$ than $\mathrm{B} 4$ after thawing (control group) and after all sperm challenges (TCG, CCG, and CTCG). However, despite B3 and B4 having demonstrated a similar percentage of plasma membrane integrity (PMI) to the control group (B3 $=66.7 \pm 1.3$ and $\mathrm{B} 4=65.2 \pm 3.3$ ), B3 demonstrated higher $(\mathrm{P} \leq 0.05)$ percentage of $\mathrm{PMI}(37.2 \pm 2.5)$ than $\mathrm{B} 4(26.7 \pm 3.3)$ after passing through the most stressing in vitro challenge (CTCG). The semen batch presenting the highest resistance to in vitro challenges was the one that presented a trend for higher in vivo fertility, suggesting that submitting semen samples to laboratory challenges may be an interesting alternative for selecting batches with greater field fertility.
\end{abstract}

Keywords: Conception rate. In vitro sperm resistance. Timed-AI.

\section{Resumo}

O objetivo deste estudo foi estressar células espermáticas em diferentes desafios laboratoriais e comparar os resultados in vitro com a fertilidade in vivo do sêmen. Quatro partidas de um mesmo touro Brangus foram utilizadas em um programa de IATF de 332 vacas Brangus. Cada partida foi submetida ao seguinte procedimento: a amostra de sêmen foi descongelada a $36^{\circ} \mathrm{C}$ por 30 segundos (grupo controle). Foram avaliados parâmetros de motilidade espermática (CASA), integridade da membrana plasmática (PMI), morfologia e concentração espermática. Em seguida, uma alíquota da amostra descongelada foi incubada em banho-maria a $45^{\circ} \mathrm{C}$ durante 40 minutos (grupo de desafio térmico, TCG) e outra alíquota foi centrifugada a $500 \mathrm{xg}$ (gradiente de Percoll 45\%/90\%) durante 15 min (grupo desafio de centrifugação, CCG). Uma aliquota do sêmen centrifugado foi ainda submetida ao desafio térmico, sendo incubado a $45^{\circ} \mathrm{C}$ durante $40 \mathrm{~min}$ (grupo de desafio térmico + centrifugação, CTCG). No final de cada desafio (CCG, TCG e CTCG), os mesmos testes laboratoriais utilizados para o grupo de controle foram realizados. A seguinte taxa de concepção (CR) foi observada para cada partida (B): B1 = 48,9\% (44/90), B2 = 44,2\% (23/52), B3 = 55,5\% (40/72) e $\mathrm{B} 4=43,2 \%$ (51/118); $(\mathrm{P}<0,10)$. No laboratório, B3 apresentou maior $(\mathrm{P} \leq 0,05)$ motilidade progressiva $(\mathrm{PM})$ do que B4 logo após o descongelamento (grupo controle) e após todos os desafios laboratoriais (TCG, CCG e CTCG). Porém, apesar de B3 e B4 demonstrarem similar porcentagem de PMI no grupo controle (B3 = 66,7 $\pm 1,3$ e B4 =65,2 $\pm 3,3)$, B3 apresentou maior $(\mathrm{P} \leq 0,05)$ PMI $(37,2 \pm 2,5 \%)$ do que B4 $(26,7 \pm 3,3 \%)$ após passar pelo maior desafio 
laboratorial (CTCG). A partida seminal que in vitro apresentou maior resistência aos desafios laboratoriais foi a mesma que apresentou tendência para maior fertilidade in vivo. Assim, sugere-se que submeter amostras seminais a desafios laboratoriais pode ser uma alternativa interessante para selecionar partidas com maior fertilidade a campo.

Palavras-chave: Taxa de concepção. Resistência espermática in vitro. IATF.

Correspondence to:

Letícia Zoccolaro Oliveira

Universidade Federal de Minas Gerais,

Escola de Veterinária

Av. Antônio Carlos, 6627 - Campus Pampulha

CEP 31270-901, Caixa Postal 567, Belo Horizonte, MG, Brazil

e-mail: leticiazoccolaro@yahoo.com.br

Received: 03/06/2017

Approved: 29/08/2017

\section{Introduction}

Several factors influencing female reproductive success have been intensely studied in that last decades by researchers of bovines (BÓ et al., 2003; BARUSELLI et al., 2004; PERRY et al., 2007; MENEGHETTI et al., 2009; SÁ FILHO et al., 2009). However, factors related to semen fertility need to receive more attention (SUGULLE et al., 2006; OLIVEIRA et al., 2012a; SUTOVSKY, 2015).

It has been widely reported that sires and/or semen batches may differ in their sperm ability of fertilizing oocytes and/or completing embryo development after in vitro fertilization (IVF) (MARQUANT-LE GUIENNE et al., 1990; WEI; FUKUI, 1999; SUDANO et al., 2011). Similarly, several studies already demonstrated varied conception rates depending on the semen batch and/ or sire utilized (CORREA et al., 1997; ZHANG et al., 1999; ANDERSSON et al. 2004; SÁ FILHO et al., 2009; OLIVEIRA et al., 2013; SANTOS, 2016). According to Sellem et al. (2015), predicting in vivo fertility of bull ejaculates based on in vitro semen characteristics remains challenging for the breeding industry.

In this sense, many studies have been conducted in order to develop laboratory tests that could predict frozen-thawed semen reproductive performance (TARTAGLIONE; RITTA, 2004). However, classic and modern laboratory tests of semen quality are still unable to accurately estimate real sperm-fertilizing capacity. Though clear that identifying a practical in vitro semen analysis for predicting field fertility would be of great benefit to the semen industry, it is unlikely that the assessment of a single sperm characteristic may reflect the real fertilizing capacity of a semen sample (ARRUDA et al., 2011; OLIVEIRA et al., 2013), especially if we consider the complexity of the reproductive process. Hence, multiple independent variables are often necessary in order to make a reasonably accurate prediction (UTT, 2016). For this reason, it is necessary to associate different semen quality tests so to improve the accuracy of a bull's reproductive potential (JANUSKAUSKAS et al., 2003; RODRIGUEZ-MARTINEZ, 2003; TARTAGLIONE; RITTA, 2004; KASTELIC; THUNDATHIL, 2008; ARRUDA et al., 2011; OLIVEIRA et al., 2013; SELLEM et al., 2015; CELEGHINI et al., 2017).

It is important to consider that the semen pathway through the female reproductive tract consists of complex challenges to sperm cells from insemination to the site of fertilization. Hence, we believe that assessing sperm quality without any cellular stress may not allow the detection of sublethal damage immediately after thawing. Therefore, this study aimed at exploring in vitro sperm characteristics of different frozen-thawed batches and their resistance to different laboratory challenges and at comparing them with in vivo fertility results.

\section{Material and Methods}

\section{Field experiment}

In order to assess field fertility, data from conception rate after timed-AI of 332 suckled multiparous Brangus cows from a commercial beef farm (located in Mato Grosso do Sul, Brazil) were utilized. For insemination of these cows, two AI technitians from this farm used four batches from the same Brangus bull.

All cows whose data were used in this study $(\mathrm{n}=332)$ presented 40-50 days postpartum and were maintained on Brachiaria brizantha or Brachiaria decumbens pasture, with ad libitum access to water and mineralized salt. Data were collected during Brazilian summer season of 2015 (breeding season). Cows presented a body condition score (BCS) between 2.25 and 3.00 on a scale from 1 to 5 (1: emaciated, 5: obese). After calving, suckled cows were allocated into three breeding groups (approximately 110 animals each), according to calving date. 
All cows received the same timed-AI protocol for first service. This protocol started (Day 0 ) with insertion of a new intravaginal progesterone-releasing device (Sincrogest; Ouro Fino Saúde Animal, Cravinhos, SP, Brazil) and $2.0 \mathrm{mg}$ of estradiol benzoate im (Sincrodiol; Ouro Fino Saúde Animal). The progesterone device was removed 8 days later, when $500 \mu \mathrm{g}$ of d-cloprostenol im (Sincrocio ${ }^{\circledR}$; Ouro Fino Saúde Animal), 300 IU of eCG im (Novormon ${ }^{\circledR}$ 5000; Zoetis, São Paulo, SP, Brazil), and $0.5 \mathrm{mg}$ of estradiol cipionate im (E.C.P ${ }^{\circledR}$, Zoetis) were administrated. Cows were timed-inseminated by two experienced AI technicians on day 10 (two days after progesterone device removal). BCS (1 to 5), semen batch (B), and AI technician were recorded for each cow on day 10 . Four semen batches were used, being randomly distributed.

Semen thawing and semen handling protocols were performed according to routine timed-AI procedures of the farm where the experiment was conducted. Hence, for each AI, the following procedure was performed: after loading a random cow in the chute, five $0.5 \mathrm{~mL}$ of frozen semen straws from the same batch were thawed simultaneously in a thermostatically controlled thawing bath (electrical water-bath unit for embryo and sperm thawing; WTA, Ribeirão Preto, SP, Brazil), adjusted to $36^{\circ} \mathrm{C}$. Thirty seconds after insertion of 5 straws into the thawing bath, one straw was removed (first straw) and immediately loaded in the AI gun. A skilled person was designated only for removing semen from thawing bath and loading AI guns. Thus, one of the two AI technicians received a prepared AI gun and immediately used it for AI. One chute was used for breeding cows, with inseminators alternating (breeding one cow and allowing the other inseminator to breed the next cow). During insemination using the first straw, a second straw was removed from thawing bath and a second AI gun was prepared. After the first AI was finished, another cow was randomly loaded in the chute and the AI gun with a second straw was used. Similarly, the other straws were loaded in AI guns and used in sequence until the $5^{\text {th }}$ straw. Next, the same procedure was repeated with another semen batch.

Semen handling and thawing procedures, AI gun preparation, and inseminations were done in a covered area (to avoid direct sunlight). During the thawing process the water-bath was agitated slightly in order to avoid direct contact between semen straws. To assure a randomized experimental design and a balanced number of animals per field variable, semen from the four batches were equally distributed across breeding groups and AI technicians. Semen cane and canister of the nitrogen tank used were organized and identified with a batch number. In addition, the subsequent group of straws was guaranteed to be different from the batch thawed before (OLIVEIRA et al., 2012a).

Semen doses were purchased from the same commercial AI company. Batches were not identified according to collection date, so it was not possible to know the distance between semen collection moments.

All cows were examined by transrectal ultrasonography 45 days after timed-AI. Detection of an embryonic vesicle with viable embryo (presence of heartbeat) was used as an indicator of pregnancy.

\section{Laboratory experiment}

\section{Laboratory challenges}

Frozen semen samples from the same batches $(n=4)$ used in the field trial were evaluated in a laboratory study. Three repetitions of laboratory experiments were carried for each batch $(\mathrm{n}=12)$.

Each dose of semen was submitted to the following procedure: initially semen sample was thawed at $36^{\circ} \mathrm{C}$ for $30 \mathrm{~s}$ in a thermostatically controlled thawing bath (WTA, Ribeirão Preto, SP, Brazil), being considered the control group. Sperm cells of Control group were submitted to optical microscopy for sperm concentration and morphology assessment. In addition, sperm motility parameters were assessed by computer assisted semen analysis (CASA) and plasma membrane integrity was evaluated by propidium iodide (PI) fluorescent probe.

Then, a $150 \mu \mathrm{L}$ aliquot of thawed sample was incubated in a water bath at $45^{\circ} \mathrm{C}$ for $40 \mathrm{~min}$, being considered the thermal challenge group (TCG). Simultaneously, another aliquot of $150 \mu \mathrm{L}$ was centrifuged at $500 \mathrm{xg}$ in a discontinuous density gradient compounded by $750 \mu \mathrm{L}$ of $45 \%$ Percoll over $750 \mu \mathrm{L}$ of $90 \%$ Percoll (45\%/90\% Percoll gradient; Pharmacia Fine Chemicals, Uppsala, Sweden) for $15 \mathrm{~min}$, being considered the centrifugation challenge group (CCG). Pellet $(150 \mu \mathrm{L})$ of centrifuged semen was also submitted to a further thermal challenge, incubated in water bath $\left(45^{\circ} \mathrm{C}\right)$ for $40 \mathrm{~min}$, being considered the centrifugation plus thermal challenge group (CTCG). At the end of each challenge (TCG, CCG and CTCG) the same sperm laboratory analyses performed for the control group were repeated. As previously stated, three repetitions of 
this experimental design were performed for each batch. Finally, the results of control group, TCG, CCG, and CTCG were compared to evaluate which laboratory challenge was more related to field fertility results (CR after timed-AI) of the respective batches assessed.

Shortly, the following steps were accomplished for each semen dose to perform laboratory challenges:

Step 1: Initially, the frozen semen sample $(500 \mu \mathrm{L})$ was thawed at $36^{\circ} \mathrm{C}$ during $30 \mathrm{~s}$ (control group). Then, an aliquot of $6 \mu \mathrm{L}$ was used for computerized analysis of sperm movement (CASA), an aliquot of $10 \mu \mathrm{L}$ was used to assess plasma membrane integrity by PI fluorescent probe (epifluorescence microscopy), an aliquot of $50 \mu \mathrm{L}$ was used to assess sperm morphology, and an aliquot of $10 \mu \mathrm{L}$ for the evaluation of sperm concentration.

Step 2: A $150 \mu \mathrm{L}$ aliquot of the control sample was incubated in a water bath at $45^{\circ} \mathrm{C}$ for $40 \mathrm{~min}$. After 40 min incubation, the same laboratory tests mentioned above were performed. (TCG)

Step 3: Simultaneously with step 2, another $150 \mu \mathrm{L}$ aliquot of the control sample was centrifuged at 500 $\mathrm{xg}$ in a 45\%/90\% Percoll gradient during $15 \mathrm{~min}$. After centrifugation, the supernatant was removed and $300 \mu \mathrm{L}$ of centrifuged semen in Percoll solution was left in the tube. The same laboratory tests mentioned above were accomplished (CCG).

Step 4: The centrifuged semen was then subjected to a further thermal challenge. Hence, a $150 \mu \mathrm{L}$ aliquot of the final pellet was incubated in a water bath at $45^{\circ} \mathrm{C}$ for 40 $\min$. After $40 \mathrm{~min}$ incubation, the same laboratory tests mentioned above were performed (CTCG).

\section{Laboratory analyses}

\section{Computer-assisted semen analysis (CASA)}

Sperm motility was assessed by CASA (IvosUltimate; Hamilton Thorne Biosciences, Beverly, MA, USA). CASA set-up was pre-adjusted for bovine sperm analysis (number of frames: 30; frames per second: 60 $\mathrm{Hz}$; minimum contrast: 50; minimum cell size: 6 pixels; contrast to static cells: 30 ; straightness: $60 \%$; average path velocity cutoff: $30 \mu \mathrm{m} / \mathrm{s}^{-1}$; minimum average path velocity: $40 \mu \mathrm{m} / \mathrm{s}^{-1}$; straight-line velocity cutoff: $20 \mu \mathrm{m} / \mathrm{s}^{-1}$; cell size: 6 pixels; cell intensity: 80; static head size: $0.23-1.91$; static head intensity: 0.56-1.20; static elongation: 8-92; magnification: $1.89 \mathrm{x}$; video frequency: 60; illumination intensity: 2203 ; temperature: $37^{\circ} \mathrm{C}$ ).
Six microlitres of the sample were placed in a standard count analysis chamber (SC20.01.FA; $20 \mu$ m; Leja, NieuwVennep, The Netherlands). Six fields were randomly selected for each analysis. The following variables were analysed: total motility (TM, \%), progressive motility (PM, \%), average path velocity (VAP, $\mu \mathrm{m} / \mathrm{s}^{-1}$ ), straightline velocity (VSL, $\mu \mathrm{m} / \mathrm{s}^{-1}$ ), curvilinear velocity (VCL, $\mu \mathrm{m} /$ $\left.\mathrm{s}^{-1}\right)$, amplitude of lateral head displacement (ALH, $\left.\mu \mathrm{m}\right)$, beat cross frequency (BCF, Hz), straightness (STR, \%), linearity (LIN, \%), and the percentage of rapidly moving cells (RAPID, \%).

\section{Evaluation of plasma membrane integrity assessed by Propidium lodide fluorescente probe}

Propidium iodide (PI) fluorescent probe is a specific DNA stain that emits a red fluorescence when bound to the nucleus of a damaged plasma membrane cell (GRAHAM et al., 1990). In the present study, PI (Sigma, 28,707-5) was utilized for assessment of plasma membrane integrity, according to adaptations of the protocol proposed by Celeghini et al. (2007).

Hence, an aliquot $(10 \mu \mathrm{L})$ of each semen sample was transferred to a pre-warmed $\left(37^{\circ} \mathrm{C}\right)$ microcentrifuge tube $(1.5 \mathrm{~mL})$ and diluted in TALP sperm medium to a final concentration of $25 \times 10^{6}$ spermatozoa $/ \mathrm{mL}$. Then, $2 \mu \mathrm{L}$ of PI solution ( $0.5 \mathrm{mg} / \mathrm{mL}$ in Dulbelco's PBS) were added to the diluted semen, which was incubated at $37^{\circ} \mathrm{C}$ for 10 min. After incubation, $6 \mu \mathrm{L}$ of the sample were transferred to a slide, coverslipped and immediately analysed by epifluorescence microscopy (LEICA ${ }^{\circledR}$, Solms, Germany) at 1000X magnification using a fluorescence filter (excitation at 540-525 $\mathrm{nm}$ and emission at $605-655 \mathrm{~nm}$ ).

A total of 200 sperm cells were examined per slide and classified according to the fluorescence emitted by PI fluorescence probe, allowing the identification of spermatozoa with intact plasma membrane (no staining) or damaged plasma membrane (presenting red fluorescence).

\section{Sperm morphology and concentration}

To assess sperm morphology semen samples were diluted and fixed in pre-warmed $\left(37^{\circ} \mathrm{C}\right)$ formaldehydePBS. Sperm cells $(n=200)$ were counted under differential interference-contrast microscopy (model 80i; Nikon, Tokyo, Japan) at a magnification of 1000X. Sperm Morphological characteristics were classified as major, minor, and total defects according to Blom (1973). 
Sperm concentration was determined by counting the sperm, with the use of a Neubauer chamber under regular optical microscope with magnification of 400X.

\section{Statistical analysis}

Pregnancy/AI (CR) 45 days after timed-AI was analysed as a binary response variable using logistic regression by the LOGISTIC procedure of SAS (version 9.3, SAS Institute, Inc., Cary, NC, USA). Variables considered in the initial models as fixed effects were breeding group (1 to 3, class), BCS (2.25/2.50 and 2.75/3.00, class), AI technician (1 and 2, class), and batches (1, 2, 3 and 4). Statistical differences in CR for each selected variable were analysed by logistic regression using least squares means (LS Means) statement of the GLIMMIX procedure. Significant difference was considered when $\mathrm{p}<0.05$.

In the present experiment, four semen batches of the same bull were investigated. For each batch, three laboratory trials were accomplished. Results obtained from all sperm variables of laboratory analyses were tested for normality of residues and homogeneity of variance. Dependent variables that did not meet these statistical premises (MT, MP, RAPID, ALH, STR, PMI) were submitted to arcsine transformation. To compare sperm characteristics after the laboratory challenges (control, CCG, TCG, and CTCG), data were submitted to ANOVA (PROC GLM) and differences were separated using Tukey's test. Results are presented as mean $\pm \mathrm{SD}$, and $\mathrm{p}<0.05$ was considered significant.

\section{Results and Discussion}

Assessment of bovine semen quality in AI industry is mostly limited to assessment of sperm motility and morphology. Traditional breeding soundness evaluation usually identify bulls and/or ejaculates with evident abnormalities and/or grossly deficits in fertility, but does not consistently identify sub-fertile bulls nor high fertile bulls (ZHANG et al., 1999; KASTELIC; THUNDATHIL, 2008; UTT, 2016; CELEGHINI et al., 2017). Considering that sperm transit until site of fertilization involves significant challenges to these cells, this study was based on the assumption that semen batches with higher resistance to laboratory challenges (stressing sperm cells) would present greater conception rates. Although no statistical difference was observed among batches in field trial, B3 presented statistical tendency $(\mathrm{p}<0.10)$ for higher $\mathrm{CR}$ than $\mathrm{B} 4$. Interesting to note that $\mathrm{B} 3$ also was more resistant to the main laboratory challenge (CTCG).
Overall CR at 45 days post timed-AI was $47.59 \%$ (158/332). No difference was observed for CR among AI-technician, BCS, or breeding groups ( $\mathrm{p}>0.05$ ). Although no statistical difference was observed between batches, it was possible to notice a statistical tendency ( $\mathrm{p}<0.1$ ) for higher CR of B3 (55.55\%; 40/72) compared with B4 (43.22\%; 51/118), and similar CR for B1 (48.88\%; $44 / 90)$ and B2 (44.23\%; 23/52).

For suckled beef cows, negative energy balance and calf presence are crucial factors interfering with ovulation success and conception rates (MENEGHETTI et al., 2009). In addition, BCS, AI technician, farm, breeding groups, and sire/semen quality are other factors affecting timedAI outcomes (PERRY et al., 2007; SÁ FILHO et al., 2009; SALES et al., 2011; CELEGHINI et al., 2017). The absence of these effects (BCS, AI technician, and breeding groups) on CR in the present study may be due to the fact that breeding groups were well distributed across the timedAI variables, all animals were cows in the same category (suckled multiparous Brangus cows), only two skilled AI technicians inseminated cows, and all animals presented small variation in BCS range (2.25 to 3.00).

It is noteworthy, though, that a numerically higher CR (statistical tendency; p < 0.1) was observed for B3 (56\%) compared to B4 (43\%). In this sense, several researchers have reported a marked variability in field fertility among sires and/or batches (CORREA et al., 1997; WARD et al., 2001; ANDERSSON et al., 2004; OLIVEIRA et al., 2012a). Differences in field fertility could be attributed to variations in sperm-qualitative characteristics (CORREA et al., 1997). Different ejaculates from the same bull may present different qualitative and/or quantitative sperm traits, depending on several factors as age, animal handling, nutrition, season of the year, animal health, and others. Hence, semen quality may vary along a bull's reproductive life, and even fertile bulls may produce ejaculates with poor fertilizing capacities, depending on their environment and/ or day of semen collection (BRITO et al., 2002; KASTELIC; THUNDATHIL, 2008; SELLEM et al., 2015).

Regarding to simultaneous thawing procedure utilized, a secure number of straws being thawed in the same moment was guaranteed. According to a previous work, the sequence of insemination after simultaneous thawing of multiple semen straws might affect fertility outcomes, depending on the sire utilized for timed-AI. Under similar environmental conditions of the present study it was demonstrated to be more cautious to not exceed six 
semen straws of $0.5 \mathrm{~mL}$ for simultaneous thawing, because it could affect conception rates (OLIVEIRA et al., 2012a). Therefore, only five semen straws of each batch were thawed at once in order to avoid possible intereferences of incubation time in CR, which could have been more or less affected according to the semen batch utilized.
Significant and interesting differences between batches 3 and 4 were observed for some in vitro sperm characteristics after stressing cells through laboratory challenges. The results of motility parameters assessed by CASA after in vitro sperm challenges are demonstrated in tables 1 and 2 .

Table 1 - Mean ( \pm SD) of total motility (TM; \%), progressive motility (PM; \%), rapidly moving cells (RAPID; \%), average path velocity (VAP; $\left.\mu \mathrm{m} / \mathrm{s}^{-1}\right)$, straight-line velocity $\left(\mathrm{VSL} ; \mu \mathrm{m} / \mathrm{s}^{-1}\right)$, and curvilinear velocity $\left(\mathrm{VCL} ; \mu \mathrm{m} / \mathrm{s}^{-1}\right.$ ) assessed by computer assisted semen analysis (CASA) after different laboratory challenges using different batches from a Brangus bull Sertãozinho, SP - January 2016

\begin{tabular}{|c|c|c|c|c|c|c|}
\hline Group & Parameters & Batch 1 & Batch 2 & Batch 3 & Batch 4 & P value \\
\hline \multirow[t]{6}{*}{ Control } & TM & $74.25 \pm 8.14 \mathrm{ab}$ & $80.50 \pm 4.80 a$ & $82.00 \pm 4.16 a$ & $62.00 \pm 10.03 b$ & 0.0078 \\
\hline & PM & $52.25 \pm 4.57 \mathrm{ab}$ & $56.50 \pm 4.43 a$ & $63.00 \pm 5.35 a$ & $47.25 \pm 6.54 b$ & 0.0176 \\
\hline & RAPID & $71.50 \pm 8.54 a b$ & $72.25 \pm 11.82 \mathrm{ab}$ & $79.75 \pm 4.11 \mathrm{a}$ & $59.00 \pm 10.74 b$ & 0.0112 \\
\hline & VAP & $97.03 \pm 7.04$ & $87.00 \pm 2.56$ & $96.35 \pm 9.27$ & $87.55 \pm 11.66$ & 0.0937 \\
\hline & VSL & $75.90 \pm 5.57$ & $68.30 \pm 1.51$ & $79.23 \pm 10.00$ & $72.00 \pm 9.77$ & 0.1619 \\
\hline & VCL & $158.20 \pm 8.89$ & $139.55 \pm 4.57$ & $153.90 \pm 16.45$ & $139.65 \pm 19.67$ & 0.1147 \\
\hline \multirow[t]{6}{*}{ TCG } & TM & $67.00 \pm 12.17 \mathrm{ab}$ & $61.33 \pm 9.29 a b$ & $79.33 \pm 0.58 a$ & $54.00 \pm 6.56 b$ & 0.0218 \\
\hline & PM & $51.33 \pm 5.86 a b$ & $46.33 \pm 6.43 a b$ & $56.00 \pm 1.73 a$ & $40.00 \pm 4.58 \mathrm{~b}$ & 0.0299 \\
\hline & RAPID & $64.33 \pm 11.85 a b$ & $56.33 \pm 9.29 a b$ & $74.00 \pm 2.00 \mathrm{a}$ & $50.67 \pm 6.11 b$ & 0.0375 \\
\hline & VAP & $79.27 \pm 5.56$ & $69.33 \pm 1.55$ & $72.77 \pm 3.20$ & $74.40 \pm 3.21$ & 0.1072 \\
\hline & VSL & $62.57 \pm 5.65$ & $56.07 \pm 1.44$ & $56.87 \pm 1.92$ & $57.93 \pm 2.77$ & 0.2274 \\
\hline & VCL & $130.07 \pm 7.49 a$ & $110.20 \pm 5.31 \mathrm{~b}$ & $117.87 \pm 5.34 \mathrm{ab}$ & $121.20 \pm 4.65 a$ & 0.0447 \\
\hline \multirow[t]{6}{*}{ CCG } & TM & $66.00 \pm 13.59 a b$ & $61.50 \pm 12.37 \mathrm{ab}$ & $71.00 \pm 12.83 a$ & $49.00 \pm 6.16 b$ & 0.0286 \\
\hline & PM & $59.00 \pm 12.25 \mathrm{ab}$ & $55.75 \pm 10.18 \mathrm{ab}$ & $64.25 \pm 12.50 \mathrm{a}$ & $45.75 \pm 7.27 b$ & 0.0471 \\
\hline & RAPID & $63.50 \pm 13.80 \mathrm{ab}$ & $59.25 \pm 12.09 \mathrm{ab}$ & $68.50 \pm 13.40 \mathrm{a}$ & $46.25 \pm 7.41 b$ & 0.0286 \\
\hline & VAP & $99.33 \pm 5.99$ & $88.28 \pm 7.42$ & $94.35 \pm 6.35$ & $94.60 \pm 10.26$ & 0.0571 \\
\hline & VSL & $89.30 \pm 3.11$ & $79.93 \pm 6.17$ & $86.03 \pm 6.01$ & $88.70 \pm 11.34$ & 0.0533 \\
\hline & VCL & $152.43 \pm 15.05$ & $133.85 \pm 11.00$ & $138.95 \pm 9.24$ & $135.68 \pm 10.47$ & 0.1029 \\
\hline \multirow[t]{6}{*}{ CTCG } & TM & $8.67 \pm 4.16 \mathrm{ab}$ & $4.33 \pm 2.52 b$ & $11.00 \pm 3.46 a$ & $6.67 \pm 8.81 \mathrm{ab}$ & 0.0500 \\
\hline & PM & $7.67 \pm 3.21 \mathrm{a}$ & $3.33 \pm 2.31 b$ & $7.67 \pm 3.79 a$ & $4.67 \pm 7.23 b$ & 0.0538 \\
\hline & RAPID & $7.67 \pm 3.21$ & $3.33 \pm 2.31$ & $8.00 \pm 3.46$ & $4.67 \pm 7.23$ & 0.0621 \\
\hline & VAP & $67.17 \pm 4.07$ & $62.40 \pm 12.97$ & $55.77 \pm 6.63$ & $58.93 \pm 1.02$ & 0.2000 \\
\hline & VSL & $64.70 \pm 4.45$ & $59.20 \pm 12.87$ & $52.17 \pm 6.87$ & $56.60 \pm 1.83$ & 0.2000 \\
\hline & VCL & $82.77 \pm 7.03$ & $77.33 \pm 18.18$ & $73.63 \pm 7.48$ & $73.70 \pm 2.46$ & 0.1694 \\
\hline
\end{tabular}

a,b: diferent letters in the same line indicate significant difference;

TCG: Thermal Challenge Group; CCG: Centrifugation Challenge Group; CTCG: Centrifugation + Thermal Challenge Group 
Table 2 - Mean ( \pm SD) of amplitude of lateral head displacement (ALH; $\mu \mathrm{m})$, beat cross frequency (BCF; Hz), straightness (STR; $\%)$, and linearity (LIN; \%) assessed by computer assisted semen analysis (CASA) after different laboratory challenges using different batches from a Brangus bull - Sertãozinho, SP - January 2016

\begin{tabular}{|c|c|c|c|c|c|c|}
\hline Group & Parameters & Batch 1 & Batch 2 & Batch 3 & Batch 4 & P value \\
\hline \multirow[t]{4}{*}{ Control } & ALH & $7.13 \pm 0.36 a$ & $6.23 \pm 0.29 b$ & $6.28 \pm 0.36 b$ & $6.18 \pm 0.46 b$ & 0.0231 \\
\hline & BCF & $21.13 \pm 1.39 a$ & $25.70 \pm 1.97 \mathrm{ab}$ & $30.83 \pm 6.29 b$ & $24.28 \pm 4.46 \mathrm{ab}$ & 0.0471 \\
\hline & STR & $78.00 \pm 1.83$ & $78.50 \pm 1.73$ & $81.75 \pm 2.87$ & $81.75 \pm 0.50$ & 0.1143 \\
\hline & LIN & $49.50 \pm 1.00 \mathrm{a}$ & $50.75 \pm 2.22 \mathrm{ab}$ & $52.75 \pm 1.50 \mathrm{~b}$ & $53.25 \pm 0.96 b$ & 0.0286 \\
\hline \multirow[t]{4}{*}{ TCG } & ALH & $6.37 \pm 0.15 \mathrm{a}$ & $5.30 \pm 0.26 b$ & $5.80 \pm 0.26 b$ & $6.60 \pm 0.26 a$ & 0.0208 \\
\hline & BCF & $19.37 \pm 0.85 a b$ & $21.93 \pm 2.20 \mathrm{ab}$ & $22.57 \pm 0.15 a$ & $17.07 \pm 0.75 b$ & 0.0064 \\
\hline & STR & $79.33 \pm 2.52$ & $81.33 \pm 1.15$ & $78.67 \pm 1.15$ & $78.33 \pm 0.58$ & 0.1000 \\
\hline & LIN & $50.00 \pm 3.61$ & $52.33 \pm 2.52$ & $50.00 \pm 1.00$ & $49.67 \pm 0.58$ & 0.3784 \\
\hline \multirow[t]{4}{*}{ CCG } & ALH & $5.83 \pm 0.83$ & $5.10 \pm 0.57$ & $5.18 \pm 0.25$ & $4.93 \pm 0.32$ & 0.3429 \\
\hline & BCF & $32.95 \pm 3.37$ & $32.40 \pm 2.09$ & $34.50 \pm 2.95$ & $34.05 \pm 3.25$ & 0.6580 \\
\hline & STR & $89.25 \pm 2.87$ & $90.25 \pm 2.22$ & $91.25 \pm 0.96$ & $93.00 \pm 1.83$ & 0.1143 \\
\hline & LIN & $60.50 \pm 4.65$ & $62.25 \pm 4.19$ & $63.75 \pm 2.06$ & $66.00 \pm 3.92$ & 0.1303 \\
\hline \multirow[t]{4}{*}{ CTCG } & ALH & $2.80 \pm 0.46$ & $2.60 \pm 0.36$ & $2.93 \pm 0.40$ & $2.73 \pm 0.42$ & 0.3646 \\
\hline & BCF & $32.13 \pm 1.18$ & $26.50 \pm 5.09$ & $32.40 \pm 0.56$ & $34.93 \pm 6.16$ & 0.2000 \\
\hline & STR & $96.00 \pm 0.10$ & $94.00 \pm 1.73$ & $93.00 \pm 1.00$ & $95.00 \pm 4.36$ & 0.7000 \\
\hline & LIN & $78.67 \pm 1.53$ & $77.33 \pm 8.62$ & $70.00 \pm 2.65$ & $76.00 \pm 3.61$ & 0.1000 \\
\hline
\end{tabular}

a,b: diferent letters in the same line indicate significant difference; Control Group: frozen-thawed semen $\left(36^{\circ} \mathrm{C}\right.$ for $30 \mathrm{~s}$ ); TCG (Thermal Challenge Group): frozenthawed semen incubated at $45^{\circ} \mathrm{C}$ for $30 \mathrm{~min}$ ); CCG (Centrifugation Challenge Group): frozen-thawed semen centrifuged in $45 \% / 90 \%$ Percoll gradient at $500 \mathrm{xg}$ for 15 min; CTCG (Centrifugation + Thermal Challenge Group): frozen-thawed semen centrifuged in $45 \% / 90 \%$ Percoll gradient ( $50 \mathrm{xg} / 15 \mathrm{~min})$ incubated at $45^{\circ} \mathrm{C}$ for $30 \mathrm{~min}$

Sperm motility is an important characteristic associated with semen fertilizing capacity (VERSTEGEN et al., 2002). Arruda et al. (1992) demonstrated no statistical differences in field fertility of cows inseminated with semen presenting progressive motility from $20 \%$ to $50 \%$ after incubation at $45^{\circ} \mathrm{C}$ for one hour. In our study, there was also no statistical difference on CR between batches and differences in PM between them was always lower than $30 \%$, regardless of the treatment to which they were submitted.

After thawing (control group) B3 presented higher PM than B4. The better performance of B3 compared to $\mathrm{B} 4$ regarding the percentage of sperm cells moving forward in a progressive manner was mainted after all in vitro challenges. In a previous work, our research group demonstrated that $\mathrm{PM}$ at $\mathrm{Oh}$ incubation (frozen-thawed semen) and/or at $2 \mathrm{~h}$ incubation $\left(37^{\circ} \mathrm{C}\right)$ were CASA parameters considered to be important predictors of in vivo bull fertility (OLIVEIRA e al., 2013).

The ALH is also a sperm parameter that can affect fertility since large amplitude of lateral head displacement may interfere in sperm hydrodynamics and their travel to fertilization site (BARLOW et al., 1991). Florez-Rodriguez (2017) demonstrated higher ALH parameter for low fertility semen compared to high fertility semen. In this sense, it is interesting to note that B3 and B4 presented similar $\mathrm{ALH}$ in the control group but, after thermal challenge (TCG), B3 presented lower ALH than B4. Farrell et al. (1998) demonstrated that multiple combinations of CASA parameters presented higher correlations with bull fertility than single CASA parameters. According to the authors, the single sperm parameter TM was weakly correlated with field fertility, while combination of PM, ALH, and BCF was strongly correlated. Santos (2016) did not observe 
diferences in BCF parameter between high and low fertility batches. In the present study, although B3 and B4 were similar in control group, B3 presented better BCF value than $\mathrm{B} 4$ after the termal challenge.

In AI companies CASA is requested to identify individual ejaculates containing sperm with poor potential to provide desired fertility. The task is not to predict fertility of a semen batch, because female reproductive tract is highly selective in moving some sperm toward the fertilization site and rejecting or removing by natural mechanisms (AMANN; WABERSKI, 2014). Therefore, we ratify in this work the importance of performing motility analyses after some cellular stress (and not immediately after thawing), in order to promote a sperm challenge to these cells before assessing semen quality, increasing the chance of detecting possible sublethal damages.

Besides motility parameters, plasma membrane integrity (PMI) exerts a fundamental role in sperm fertilizing capability. PMI is essential to sperm viability, osmotic balance, selective permeability, and cellular homeostasis (FLESCH; GADELLA, 2000). Sperm cells with damaged plasma membrane become unable to accomplish oocyte fertilization (Silva; Gadella, 2006). Januskauskas et al. (2003) detected significant correlations between field fertility and PMI assessed by PI. Correa et al. (1997) demonstrated a positive correlation with PMI and high fertility bulls. Batches 3 and 4 presented similar high percentages of PMI after thawing (Control Group). However, only B3 (tendency for greater field fertility) maintained higher percentage of PMI after passing through the most intense in vitro sperm challenge (CTCG), which may indicate a higher resistance of this batch.

Results of plasma membrane integrity, sperm morphology, and concentration are presented in table 3 .

Table 3 - Mean ( \pm SD) of plasma membrane integrity (PMI; \%), sperm morphology (major, minor and total defects; \%), sperm concentration (CONC; $\left.10^{6} \mathrm{sptz} / \mathrm{mL}\right)$, and number of sperm presenting membrane integrity $\left(\mathrm{PMI}^{\star} \mathrm{CONC}\right.$; $10^{6} \mathrm{sptz} /$ $\mathrm{mL}$ ) after different laboratory challenges using different batches from a Brangus bull - Sertãozinho, SP - January 2016

\begin{tabular}{|c|c|c|c|c|c|c|}
\hline Group & Parameters & Batch 1 & Batch 2 & Batch 3 & Batch 4 & P value \\
\hline \multirow[t]{6}{*}{ Control } & PMI & $61.40 \pm 2.86 \mathrm{ab}$ & $55.50 \pm 2.38 b$ & $66.75 \pm 1.32 \mathrm{a}$ & $65.25 \pm 3.30 a$ & 0.0286 \\
\hline & Major defects & $3.33 \pm 1.53$ & $2.33 \pm 0.58$ & $2.00 \pm 1.00$ & $2.67 \pm 1.53$ & 0.2952 \\
\hline & Minor defects & $7.67 \pm 1.15$ & $7.00 \pm 1.00$ & $6.67 \pm 0.58$ & $6.67 \pm 1.15$ & 0.3638 \\
\hline & Total defects & $11.00 \pm 1.00$ & $8.25 \pm 2.22$ & $8.67 \pm 0.58$ & $9.33 \pm 0.58$ & 0.1000 \\
\hline & CONC & $34.00 \pm 4.00 \mathrm{a}$ & $9.70 \pm 2.10 \mathrm{~b}$ & $23.70 \pm 3.10 c$ & $33.40 \pm 1.50 a$ & 0.0313 \\
\hline & PMI*CONC & $20.88 \pm 3.76 \mathrm{ab}$ & $5.38 \pm 2.21 c$ & $15.82 \pm 2.09 b$ & $21.79 \pm 2.87 a$ & 0.0246 \\
\hline \multirow[t]{6}{*}{ TCG } & PMI & $52.33 \pm 14.11$ & $47.50 \pm 5.27$ & $56.50 \pm 13.26$ & $42.67 \pm 13.14$ & 0.2894 \\
\hline & Major defects & $3.33 \pm 1.53$ & $2.33 \pm 0.58$ & $2.00 \pm 1.00$ & $2.67 \pm 1.53$ & 0.2952 \\
\hline & Minor defects & $8.67 \pm 1.15$ & $8.00 \pm 1.00$ & $7.67 \pm 0.58$ & $7.67 \pm 1.15$ & 0.4000 \\
\hline & Total defects & $12.00 \pm 1.00$ & $9.00 \pm 2.71$ & $9.67 \pm 0.58$ & $10.33 \pm 0.58$ & 0.1240 \\
\hline & CONC & $34.00 \pm 4.00 \mathrm{a}$ & $9.70 \pm 2.10 \mathrm{~b}$ & $23.70 \pm 3.10 c$ & $33.4 \pm 1.50 \mathrm{a}$ & 0.0313 \\
\hline & PMI*CONC & $17.79 \pm 9.07 a$ & $4.61 \pm 2.87 b$ & $13.39 \pm 8.08 \mathrm{ab}$ & $14.25 \pm 8.98 \mathrm{ab}$ & 0.0156 \\
\hline \multirow[t]{6}{*}{ CCG } & PMI & $65.67 \pm 17.90$ & $39.17 \pm 28.56$ & $60.38 \pm 8.04$ & $55.33 \pm 11.86$ & 0.2000 \\
\hline & Major defects & $0.33 \pm 0.58$ & $0.00 \pm 0.00$ & $1.33 \pm 0.58$ & $0.67 \pm 1.15$ & 0.1819 \\
\hline & Minor defects & $1.00 \pm 0.00$ & $0.67 \pm 0.58$ & $0.33 \pm 0.58$ & $0.33 \pm 0.58$ & 0.2636 \\
\hline & Total defects & $1.33 \pm 0.58$ & $0.50 \pm 0.58$ & $1.67 \pm 1.15$ & $1.00 \pm 1.00$ & 0.3638 \\
\hline & CONC & $73.70 \pm 10.10 \mathrm{a}$ & $71.70 \pm 11.6 a$ & $103.2 \pm 6.10 b$ & $87.4 \pm 7.50 a$ & 0.0333 \\
\hline & PMI*CONC & $48.40 \pm 13.09 \mathrm{ab}$ & $28.08 \pm 18.72 b$ & $62.31 \pm 7.08 \mathrm{a}$ & $48.36 \pm 8.23 \mathrm{ab}$ & 0.0166 \\
\hline \multirow[t]{6}{*}{ CTCG } & PMI & $31.67 \pm 5.77 \mathrm{ab}$ & $25.83 \pm 1.44 b$ & $37.17 \pm 2.47 a$ & $26.27 \pm 2.32 b$ & 0.0500 \\
\hline & Major defects & $0.33 \pm 0.58$ & $0.00 \pm 0.00$ & $1.33 \pm 0.58$ & $0.67 \pm 1.15$ & 0.1819 \\
\hline & Minor defects & $2.00 \pm 0.00$ & $1.67 \pm 0.58$ & $1.33 \pm 0.58$ & $1.33 \pm 0.58$ & 0.3264 \\
\hline & Total defects & $2.33 \pm 0.58$ & $1.25 \pm 0.96$ & $2.67 \pm 1.15$ & $2.00 \pm 1.00$ & 0.3118 \\
\hline & CONC & $73.7 \pm 10.10 \mathrm{a}$ & $71.7 \pm 11.60 \mathrm{a}$ & $103.2 \pm 6.10 \mathrm{~b}$ & $87.4 \pm 7.50 \mathrm{a}$ & 0.0333 \\
\hline & PMI*CONC & $23.34 \pm 7.64 b$ & $18.52 \pm 5.35 b$ & $38.36 \pm 4.00 \mathrm{a}$ & $23.31 \pm 4.01 b$ & 0.0246 \\
\hline
\end{tabular}

a,b: diferent letters in the same line indicate significant difference;

TCG: Thermal Challenge Group; CCG: Centrifugation Challenge Group; CTCG: Centrifugation + Thermal Challenge Group 
Percoll centrifugation is a widely used method for bovine sperm selection (MCCANN; CHANTLER, 2000; PETYIM et al., 2009) mainly before IVP (CESARI et al., 2006; LEE et al., 2009; MACHADO et al., 2009). Several authors observed higher percentage of cells with intact plasma membrane in Percoll centrifuged semen (LEE et al., 2009; MACHADO et al., 2009; OLIVEIRA et al., 2012b), indicating that most dead spermatozoa present in frozen-thawed semen were retained in the upper layers of the gradient. Damaged spermatozoa are removed by a particular mechanism in Percoll separation methods (OSHIO, 1988; RHEMREV et al., 1989) and sperm progressive motility is generally improved after Percoll centrifugation (CESARI et al., 2006; LEE et al., 2009; MACHADO et al., 2009; PETYIM et al., 2009). In the present study the small amount of semen $(150 \mu \mathrm{L})$ being deposited in the upper layer of this density gradient might have avoided this phenomenon to happen. Instead, Percoll centrifugation acted as a barrier challenge to sperm cells, reducing sperm motility.

The observation that no increase in PMI was observed after Percoll centrifugation is another evidence that the Percoll barrier acted more as a sperm challenge step than as a sperm selection method, which was in fact our goal when using Percoll gradient. In this regard, Cesari et al. (2006) stated that Percoll adheres to sperm membranes removing some decapacitating proteins, which can explain why a high percentage of Percoll-selected spermatozoa could have some alterations, such as faster capacitation and membrane destabilisation. In the present study B3 demonstrated higher resistance regarding integrity of plasma membrane (PMI), which is a fundamental sperm feature to be maintained after passing through the most stressing laboratory challenge (CTCG).

However, one should not ignore the evidence that better cells were selected after passage through Percoll when the sperm morphology parameter is taken into account. Therefore, similar to the cervix and oviduct, Percoll may act as a challenging barrier for spermatozoa, operating as sperm selection technique for excluding sperm cells less capable in performing successful fertilization. There is good evidence that morphologically normal spermatozoa offer the best fertilizing potential (POUSETTE et al., 1986; VAN DER ZWALMEN et al., 1991; ARRUDA et al., 2011; OLIVEIRA et al., 2013). Van Der Zwalmen et al. (1991) demonstrated that Percoll technique selects sperm samples with better morphological quality from normal as well as from poor semen samples. Such selection led to improved fertilization rates. According to the authors, sperm cells with morphologically normal oval heads present a dense and homogeneous nucleus being selected in the more concentrated fraction of Percoll gradient.

In an ellegant study, Odhiambo et al. (2014) demonstrated that removal of defective spermatozoa from collected semen by nanotecnology may have the dual benefit of mitigating the dilution of total sperm count per AI dose by defective spermatozoa and reducing the reactive oxygen species released from decaying spermatozoa that might affect the fertilizing ability of the normal spermatozoa. Here, in a much simpler study with a cheaper technique, we would like to highlight the importance of stressing semen samples before evaluating their quality, since it is possible that some sublethal damages may appear in the laboratory before they are used in the field.

In this sense, it is worth to mention that B3 presented lower sperm concentration than B4 in control group. However, considering centrifuged groups (CCG and CTCG), it may be noticed that B3 recovered a higher number of sperm cells after passage through a Percoll gradient, which confirms that B3 had a higher number of cells with better sperm quality (and/or better sperm resistance) than B4. Sperm concentration does not change due to thermal challenges, hence these values are similar for Control and TCG, as well as for CCG and CTCG groups. Additionally, when analysing the number of sperm cells presenting integrity of plasma membrane $\left(\mathrm{PMI}^{\star} \mathrm{CONC}\right), \mathrm{B} 1$ and $\mathrm{B} 4$ demonstrated better semen quality soon after thawing (control group). However, after passing through Percoll gradient and suffering a thermal challenge (CTCG), B3 was the batch demonstrating the highest in vitro performance.

As stated above, sperm cells need to survive after undergoing several in vivo challenges inside the female reproductive tract until fertilization. The standard breeding soundness evaluation and the conventional semen quality criteria used for AI industry generally identifies bulls and ejaculates with grossly low fertilizing potential. However, sub-fertile and high fertile bulls are hard to identify. Therefore, the present work was conducted ir order to explore in vitro semen quality after stressing sperm cells, because we hypothesized that some sublethal damages affecting fertility could appear in the laboratory only if the semen batch was submitted to different laboratory challenges before assessing semen quality. Although only statistical tendency was observed for field fertility, it is noteworthy that semen batch presenting better 
reproductive performance at timed-AI also demonstrated satisfatory resistance after in vitro challenges in several laboratorial analyses.

Our group had already demonstrated that semen fertility of some sires was more negatively affected by thawing-bath environment than others, although the reason why semen from some bulls was more susceptible to specific thawing environments and/or procedures was not elucidated (OLIVEIRA et al., 2012a). Since some batches from a single bull presented higher sensitivity to in vitro challenges and/or to cellular stress than others, our results confirm that some laboratory procedures may be more or less aggressive depending on the batch utilized.

\section{Conclusion}

The results of this study demonstrated individual variation of different batches for in vitro sperm

\section{References}

AMANN, R. P.; WABERSKI, D. Computer-assisted sperm analysis (CASA): capabilities and potential developments. Theriogenology, v. 81, n. 1, p. 5-17, 2014. doi: 10.1016/j. theriogenology.2013.09.004.

ANDERSSON, M.; TAPONEN, J.; KOSKINEN, E.; DAHLBOMB, M. Effect of insemination with doses of 2 or 15 million frozen-thawed spermatozoa and semen deposition site on pregnancy rate in dairy cows. Theriogenology, v. 61, n. 7-8, p. 1583-1588, 2004. doi: 10.1016/j.theriogenology.2003.09.006.

ARRUDA, R. P.; BARNABE, V. H.; ALENCAR, M. M.; BARNABE, R. C. Avaliação de sêmen congelado de bovinos. Provas lenta e rápida de termo-resistência: efeitos sobre a fertilidade. Brazilian Journal of Veterinary Research and Animal Science, v. 29, n. 1, p. 131-137, 1992. doi: 10.11606/issn.1678-4456.bjvras.1992.51962.

ARRUDA, R. P.; CELEGHINI, E. C. C.; ALONSO, M. A.; CARVALHO, H. F.; OLIVEIRA, L. Z.; NASCIMENTO, J.; SILVA, D. F.; AFFONSO, F. J.; LEMES, K. M.; JAIMES, J. D. Methods of the assessment of morphology and function of sperm: actual moment and future challenges. Revista Brasileira de Reprodução Animal, v. 35, n. 2, p. 145-151, 2011. characteristics and resistance when submitted to different laboratory challenges. Therefore, it is reasonable to believe that combining different laboratory challenges for frozen-thawed semen before assessing sperm characteristics may improve the prediction of in vivo fertility for reproductive programs. We ratify in this work the importance of performing laboratory challenges to sperm cells before assessing semen quality (and not immediately after thawing) in order to promote some cellular stress, increasing the chance of detecting possible sublethal damages.

\section{Acknowledgements}

The authors are grateful to FAPESP for financial support in form of grant (2014/07606-4) and Agropecuária SANYO for allowing access to their data of timed-AI for this study.

BARLOW, P.; DELVIGNE, A.; VAN DROMME, J. VAN HOECK, J.; VANDENBOSCH, K.; LEROY, F. Predictive value of classical and automated sperm analysis for in vitro fertilization. Human Reproduction, v. 6, n. 8, p. 11191124, 1991. doi: 10.1093/oxfordjournals.humrep.a137496.

BARUSELLI, P. S.; REIS, E. L.; MARQUES, M. O.; NASSER, L. F.; BÓ, G. A. The use of hormonal treatments to improve reproductive performance of anestrous beef cattle in tropical climates. Animal Reproduction Science, v. 82, p. 479-486, 2004. doi: 10.1016/j.anireprosci.2004.04.025.

BLOM, E. The ultrastructure of some characteristic sperm defects and a proposal for a new classification of the bull spermogram. Nordisk Veterinaermedicin, v. 25, n. 7, p. 383-391, 1973.

BÓ, G. A.; BARUSELLI, P. S.; MARTINEZ, M. F. Pattern and manipulation of follicular development in Bos indicus cattle. Animal Reproduction Science, v. 78, n. 3-4, p. 307326, 2003. doi: 10.1016/S0378-4320(03)00097-6.

BRITO, L. F.; SILVA, A. E.; RODRIGUES, L. H.; VIEIRA, F. V.; DERAGON, L. A.; KASTELIC, J. P. Effects of environmental factors, age and genotype on sperm production and semen quality in Bos indicus and 
Bos taurus AI bulls in Brazil. Animal Reproduction Science, v. 70, n. 3-4, p.181-190, 2002. doi: 10.1016/S03784320(02)00009-X.

CELEGHINI, E. C. C.; ARRUDA, R. P.; ANDRADE, A. F. C.; NASCIMENTO, J.; RAPHAEL, C. F. Practical techniques for bovine sperm simultaneous fluorimetric assessment of plasma, acrosomal and mitochondrial membranes. Reproduction in Domestic Animals, v. 42, n. 5, p. 479-488, 2007. doi: 10.1111/j.14390531.2006.00810.x.

CELEGHINI, E. C. C.; ARRUDA, R. P.; FLOREZRODRIGUEZ, S. A.; SANTOS, F. B.; ALVES, M. B. R.; OLIVEIRA, B. M. M. Impacto da qualidade do sêmen sobre a fertilidade a campo em bovinos. Revista Brasileira de Reprodução Animal, v. 41, n. 1, p. 40-45, 2017.

CESARI, A.; KAISER, G. G.; MUCCI, N.; MUTTO, A.; VINCENTI, A.; FORNÉS, M. W.; ALBERIO, R. $\mathrm{H}$. Integrated morphophysiological assessment of two methods for sperm selection in bovine embryo production in vitro. Theriogenology, v. 66, n. 5, p. 1185-1193, 2006. doi: 10.1016/j.theriogenology.2006.03.029.

CORREA, J. R.; PACE, M. M.; ZAVOS, P. M. Relationships among frozen-thawed sperm characteristics assessed via the routine semen analysis, sperm functional tests and the fertility of bulls in an artificial insemination program. Theriogenology, v. 48, n. 5, p. 721-731, 1997. doi: 10.1016/ S0093-691X(97)00296-3.

FARRELL, P. B.; PRESICCE, G. A.; BROCKETT, C. C.; FOOTE, R. H. Quantification of bull sperm characteristics measured by computer-assisted sperm analysis (CASA) and the relationship to fertility. Theriogenology, v. 49, n. 4, p. 871-879, 1998. doi: 10.1016/S0093-691X(98)00036-3.

FLESCH, F. M.; GADELLA, B. M. Dynamics of the mammalian sperm plasma membrane in the process of fertilization. Biochimica et Biophysica Acta, v. 1469, n. 3, p. 197-235, 2000.

FLOREZ-RODRIGUEZ, S. A. Importância da qualidade espermática sobre a predição do potencial de fertilidade in vivo em bovinos: contribuição da mitocôndria e das subpopulações espermáticas. 2017. 157 f. Tese (Doutorado em Ciências) - Faculdade de Medicina Veterinária e Zootecnia, Universidade de São Paulo. São Paulo, 2017.

GRAHAM, J. K.; KUNZE, E.; HAMMERSTEDT, R. H. Analysis of sperm cell viability, acrosomal integrity, and mitochondrial function using flow cytometric. Biology of Reproduction, v. 43, n. 1, p. 55-64, 1990. doi: 10.1095/ biolreprod43.1.55.

JANUSKAUSKAS, A.; JOHANNISSON, A.; RODRIGUEZMARTINEZ,H.Subtlemembranechangesincryopreserved bull semen in relation with sperm viability, chromatin structure and field fertility. Theriogenology, v. 60, n. 4, p. 743-758, 2003. doi: 10.1016/S0093-691X(03)00050-5.

KASTELIC, J. P.; THUNDATHIL, J. C. Breeding soundness evaluation and semen analysis for predicting bull fertility. Reproduction in Domestic Animals, v. 43, p. 368-373, 2008. Suplemento. doi: 10.1111/j.14390531.2008.01186.x.

LEE, H. L.; KIM, S. H.; JI, D. B.; KIM, Y. J. A comparative study of Sephadex, glass wool and Percoll separation techniques on sperm quality and IVF results for cryopreserved bovine semen. Journal of Veterinary Science, v. 10, n. 3, p. 249-255, 2009. doi: 10.4142/ jvs.2009.10.3.249.

MACHADO, G. M.; CARVALHO, J. O.; SIQUEIRA FILHO, E.; CAIXETA, E. S.; FRANCO, M. M.; RUMPF, R.; DODE, M. A. N. Effect of Percoll volume, duration and force of centrifugation, on in vitro production and sex ratio of bovine embryos. Theriogenology, v. 71, n. 8, p. 1289-1297, 2009. doi: 10.1016/j.theriogenology.2009.01.002.

MCCANN, C. T.; CHANTLER, E. Properties of sperm separated using Percoll and IxaPrep density gradients. A comparison made using CASA, longevity, morphology and the acrosome reaction. International Journal of Andrology, v. 23, n. 4, p. 205-209, 2000. doi: 10.1046/j.13652605.2000.00228.x.

MARQUANT-LE GUIENNE, B.; HUMBLOT, P.; THIBIER, M.; THIBAULT, C. Evaluation of bull semen fertility by homologous in vitro fertilization tests. Reproduction, Nutrition, Development, v. 30, n. 2, p. 259-266, 1990. doi: 10.1051/rnd:19900212. 
MENEGHETTI, M.; SÁ FILHO, O. G.; PERES, R. F.; LAMB, G. C.; VASCONCELOS, J. L. M. Fixed time artificial insemination with estradiol and progesterone for Bos indicus cows. I. Basis for development of protocols. Theriogenology, v. 72, n. 2, p. 179-189, 2009. doi: 10.1016/j. theriogenology.2009.02.010.

ODHIAMBO, J. F.; DEJARNETTE, J. M.; GEARY, T. W.; KENNEDY, C. E.; SUAREZ, S. S.; SUTOVSKY, M.; SUTOVSKY, P. Increased conception rates in beef cattle inseminated with nanopurified bull semen. Biology of Reproduction, v. 91, n. 4, p. 1-10, 2014. doi: 10.1095/ biolreprod.114.121897.

OLIVEIRA, L. Z.; ARRUDA, R. P.; ANDRADE, A. F. C.; SANTOS, R. M.; BELETTI, M. E.; PERES, R. F. G.; MARTINS, J. P. N.; HOSSEPIAN DE LIMA, V. F. M. Effect of sequence of insemination after simultaneous thawing of multiple semen straws on conception rate to timed AI in suckled multiparous Nelore cows. Theriogenology, v. 78, n. 8, p. 1800-1813, 2012a. doi: 10.1016/j.theriogenology.2012.07.007.

OLIVEIRA, L. Z.; ARRUDA, R. P.; CELEGHINI, E. C. C.; ANDRADE, A. F. C.; PERINI, A. P.; RESENDE, M. V.; MIGUEL, M. C. V.; LUCIO, A. C.; HOSSEPIAN DE LIMA, V. F. M. Effects of discontinuous Percoll gradient centrifugation on the quality of bovine spermatozoa evaluated with CASA and fluorescente probes association. Andrologia, v. 44, n. 1, p. 9-15, 2012b. doi: 10.1111/j.14390272.2010.01096.x.

OLIVEIRA, L. Z.; SANTOS, R. M.; ARRUDA, R. P.; ANDRADE, A. F. C.; PERES, R. F. G.; MARTINS, J. P. N.; REEB, P. D.; MONTEIRO, F. M.; BELETTI, M. E.; HOSSEPIAN DE LIMA, V. F. M. Assessment of in vitro sperm characteristics and their importance in the prediction of conception rate in a bovine timed-AI program. Animal Reproduction Science, v. 137, n. 3-4, p. 145-155, 2013. doi: 10.1016/j.anireprosci.2013.01.010.

OSHIO, S. Apparent densities of spermatozoa of various mammalian species. Gamete Research, v. 20, n. 2, p. 159164, 1988. doi: 10.1002/mrd.1120200206.

PERRY, G. A.; SMITH, M. F.; ROBERTS, A. J.; MACNEIL, M. D.; GEARY, T. W. Relationship between size of ovulatory follicle and pregnancy success in beef heifers. Journal of Animal Science, v. 85, n. 3, p. 684-689, 2007. doi: 10.2527/jas.2006-519.

PETYIM, S.; CHOAVARATANA, R.; SUKSOMPONG, S.; LAOKIRKKIAT, P.; MAKEMAHARN, O. Outcome of sperm preparation using double-gradients technique study in Siriraj Hospital. Journal of the Medical Association of Thailand, v. 92, n. 7, p. 878-884, 2009.

POUSETTE, A.; AKERLOF, E.; ROSENBORG, L.; FREDRICSSON, B. Increase in progressive motility and improved morphology of human spermatozoa following their migration through Percoll gradients. International Journal of Andrology, v. 9, n. 1, p.1-13, 1986.

RHEMREV, J.; JEYENDRAN, R. S.; VERMEIDEN, J. P.; ZANEVELD, L. J. Human sperm selection by glass wool filtration and two-layer, discontinuous Percoll gradient centrifugation. Fertility and Sterility, v. 51, n. 4, p. 685690, 1989.

RODRIGUEZ-MARTINEZ, H. Laboratory semen assessment and prediction of fertility: still utopia? Reproduction in Domestic Animals, v. 38, n. 4, p. 312318, 2003. doi: 10.1046/j.1439-0531.2003.00436.x.

SÁ FILHO, O. G.; MENEGHETTI, M.; PERES, R. F. G.; LAMB, G.; VASCONCELOS, J. L. M. Fixed-time artificial insemination with estradiol and progesterone for Bos indicus cows. II. Strategies and factors affecting fertility. Theriogenology, v. 72, n. 2, p. 210-218, 2009. doi: 10.1016/j. theriogenology.2009.02.008.

SALES, J. N.; NEVES, K. A. L.; SOUZA, A. H; CREPALDI, G. A.; SALA, R. V.; FOSADO, M.; CAMPOS FILHO, E. P.; FARIA, M.; SÁ FILHO, M. F.; BARUSELLI, P. S. Timing of insemination and fertility in dairy and beef cattle receiving timed artificial insemination using sexsorted sperm. Theriogenology, v. 76, n. 3, p. 427-435, 2011. doi: 10.1016/j.theriogenology.2011.02.019.

SANTOS, F. B. Relação da qualidade do sêmen com a fertilidade após IATF em vacas de corte. 2016. 62 f. Dissertação (Mestrado em Ciências) - Faculdade de Medicina Veterinária e Zootecnia, Universidade de São Paulo, São Paulo, 2016. 
SELLEM, E.; BROEKHUIJSE, M. L.; CHEVRIER, L.; CAMUGLI, S.; SCHMITT, E.; SCHIBLER, L.; KOENEN, E. P. Use of combinations of in vitro quality assessments to predict fertility of bovine semen. Theriogenology, v. 84, n. 9, p. 1447-1454, 2015. doi: 10.1016/j.theriogenology.2015.07.035.

SILVA, P. F. N.; GADELLA, B. M. Detection of damage in mammalian sperm cells. Theriogenology, v. 65, n. 5, p. 958-978, 2006. doi: 10.1016/j.theriogenology.2005. 09.010 .

SUDANO, M. J.; CRESPILHO, A. M.; FERNANDES, C. B.; MARTINS JUNIOR, A.; PAPA, F. O.; RODRIGUES, J.; MACHADO, R.; LANDIM-ALVARENGA, F. C. Use of Bayesian inference to correlate in vitro embryo production and in vivo fertility in Zebu bulls. Veterinary Medicine International, v. 2011, p. 1-6, 2011. doi: $10.4061 / 2011 / 436381$.

SUGULLE, A. H.; BHUIYAN, M. M. U.; SHAMSUDDIN, M. Breeding soundness of bulls and the quality of their frozen semen used in cattle artificial insemination in Bangladesh. Livestock Research for Rural Development, v. 18 , n. 4 , p. 1-10, 2006.

SUTOVSKY, P. New approaches to boar semen evaluation, processing and improvement. Reproduction in Domestic Animals, v. 50, p. 11-19, 2015. Supplement. doi: 10.1111/ rda. 12554 .

TARTAGliOnE, C. M.; RITTA, M. N. Prognostic value of spermatological parameters as predictors of in vitro fertility of frozen-thawed bull semen. Theriogenology, v. 62, n. 7, p. 1245-1252, 2004. doi: 10.1016/j.theriogenology.2004.01.012
UTT, M. D. Prediction of bull fertility. Animal Reproduction Science, v. 169, p. 37-44, 2016. doi: 10.1016/j. anireprosci.2015.12.011.

VAN DER ZWALMEN, P.; BERTIN-SEGAL, G.; GEERTS, L.; DEBAUCHE, C.; SCHOYSMAN, R. Sperm morphology and IVF pregnancy rate: comparison between Percoll gradient centrifugation and swim-up procedures. Human Reproduction, v. 6, n. 4, p. 581-588, 1991. doi: 10.1093/oxfordjournals.humrep.a137383.

VERSTEGEN, J.; IGUER-OUADA, M.; OCLIN, K. Computer assisted semen analysers in andrology research and veterinary practice. Theriogenology, v. 57, n. 1, p. 149179, 2002. doi: 10.1016/S0093-691X(01)00664-1.

WARD, F.; RIZOS, D.; CORRIDAN, D.; QUINN, K.; BOLAND, M.; LONERGAN, P. Paternal influence on the time of first embryonic cleavage post insemination and the implications for subsequent bovine embryo development in vitro and fertility in vivo. Molecular Reproduction and Development, v. 60, n. 1, p. 47-55, 2001. doi: 10.1002/ mrd.1060.

WEI, H.; FUKUI, Y. Effects of bull, sperm type and sperm pretreatment on male pronuclear formation after intracytoplasmic sperm injection in cattle. Reproduction, Fertility and Development, v. 11, n. 1, p. 59-66, 1999. doi: 10.1071/RD98106.

ZHANG, B. R.; LARSSON, B.; LUNDEHEIM, N.; HAARD, M. G. H.; RODRIGUEZ-MARTINEZ, H. Prediction of bull fertility by combined in vitro assessments of frozen-thawed semen from young dairy bulls entering an Al-programme. International Journal of Andrology, v. 22, n. 4, p. 253-260, 1999. doi: 10.1046/j.1365-2605.1999.00178.x. 